\title{
In brain mitochondria, calcium and cell death-associated permeability transition are controlled by possibly associated proteins, 2','3'-CNPase, Centaurin-alphal and peripheral benzodiazepine receptor, and their substrates/ligands
}

\author{
A Galvita*1, T Azarashvili22, O Krestinina², D Grachev², Y Evtodienko², \\ R Stricker ${ }^{1}$ and G Reiser ${ }^{1}$
}

Address: ${ }^{1}$ Otto-von-Guericke-Universität Magdeburg, Medizinische Fakultät, Institut für Neurobiochemie, Germany and ${ }^{2}$ Russian Academy of Science, Institute of Theoretical and Experimental Biophysics, Pushchino, Moscow region, Russia

* Corresponding author

from 12th Joint Meeting of the Signal Transduction Society (STS). Signal Transduction: Receptors, Mediators and Genes

Weimar, Germany. 29-31 October 2008

Published: 26 February 2009

Cell Communication and Signaling 2009, 7(SuppI I):A59 doi:10.1186/1478-8IIX-7-SI-A59

This abstract is available from: http://www.biosignaling.com/content/7/SI/A59

(c) 2009 Galvita et al; licensee BioMed Central Ltd.

Mitochondria play a central role in calcium homeostasis and cellular calcium signaling. During cellular calcium overload, mitochondria take up cytosolic calcium, which, in turn, induces opening of the permeability transition pore (PTP), disruption of mitochondrial membrane potential and cell death. PTP is a protein complex changing according to the needs of the cell and responding to different external and internal stimuli. The identity of the PTP is still unresolved. 2',3'-cyclic nucleotide 3'-phosphodiesterase (CNP) and p42(IP4) (centaurin-alpha1) have been shown to be associated with rat brain mitochondria (RBM), but the exact role of these proteins in mitochondria is still obscure. Localization of p42(IP4) and CNP within the inner membrane and contact sites indicates further functions for these proteins. We found interaction of p42(IP4) with CNP by pull-down binding assay and by immunoprecipitation.

Since PTP opening is important in mitochondrial events leading to programmed cell death, we studied whether p42(IP4) and CNP are involved in calcium-induced calcium release and consequently PTP. Simultaneous measurements of the respiratory rate, trans-membrane potential and calcium transport in the mitochondrial suspension were performed. We also developed the method of isolation of functionally active mitochondria from sev- eral cell types. We determined the calciumcapacity and lag-phase for PTP opening in mitochondria isolated from p42(IP4)-transfected and from control neuroblastoma cells. Overexpression of p42(IP4) led to promotion of calcium-induced PTP opening. The enzymatic activity of CNP was reduced under PTP opening, whereas the level of CNP detected in RBM before and after PTP opening were unchanged. Involvement of CNP in PTP operation was confirmed in further experiments using mitochondria isolated from CNP-knock-down oligodendrocytes (OLN93 cells). In mitochondria isolated from OLN93 cells transfected with CNP-targeting siRNA, CNP reduction was correlated with facilitation of calcium-induced PTP opening. The CNP substrates, 2', 3'-cAMP and 2', 3'-cNADP, induced PTP opening in RBM. The peripheral-type benzodiazepine receptor (PBR) is an $18 \mathrm{kDa}$ mitochondrial membrane protein with still elusive functions. A release of pro-apoptotic factors, AIF and cytochrome c, from RBM was shown at threshold calcium load. Anti-PBR antibody blocked the release of AIF but did not affect the cytochrome c release. The endogenous PBR ligand, protoporphyrin IX, facilitated PTP opening and phosphorylation of the mitochondrial proteins, thus, inducing effects opposite to anti-PBR antibody. This study provides evidence for PBR involvement in PTP opening, controlling the calcium-induced calcium efflux, and AIF release from mitochondria. 
In summary, our results provide evidence that PBR, CNP and p42(IP4) are involved in regulation of calciuminduced PTP opening, important stage of initiation of programmed cell death.

Publish with Bio Med Central and every scientist can read your work free of charge

"BioMed Central will be the most significant development for disseminating the results of biomedical research in our lifetime. " Sir Paul Nurse, Cancer Research UK

Your research papers will be:

- available free of charge to the entire biomedical community

- peer reviewed and published immediately upon acceptance

- cited in PubMed and archived on PubMed Central

- yours - you keep the copyright

Submit your manuscript here:

http://www.biomedcentral.com/info/publishing_adv.asp 